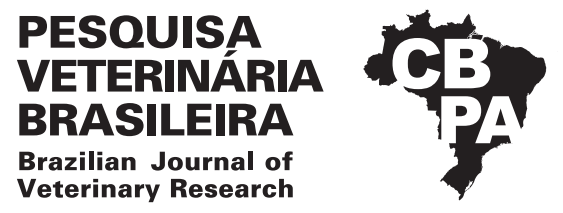

Pesq. Vet. Bras. 38(11):2056-2064, novembro 2018 DOI: 10.1590/1678-5150-PVB-6005

Original Article

Animais de Produção/Livestock Diseases

ISSN 0100-736X (Print)

ISSN 1678-5150 (Online)

\title{
Lung lesions of slaughtered horses in southern Brazil ${ }^{1}$
}

\author{
Matheus V. Bianchi², Lauren S. Mello², Cíntia De Lorenzo², Bruna C. Lopes², \\ Gustavo G.M. Snel ${ }^{2}$, David Driemeier ${ }^{2}$ and Saulo P. Pavarini ${ }^{2 *}$
}

\begin{abstract}
Bianchi M.V., Mello L.S., De Lorenzo C., Lopes B.C., Snel G.G.M., Driemeier D. \& Pavarini S.P. 2018. Lung lesions of slaughtered horses in southern Brazil. Pesquisa Veterinária Brasileira 38(11):2056-2064. Setor de Patologia Veterinária, Faculdade de Veterinária, Universidade Federal do Rio Grande do Sul, Av. Bento Gonçalves 9090, Porto Alegre, RS 91540-000, Brazil.E-mail: saulo.pavarini@ufrgs.br

Respiratory diseases cause significant veterinary costs, reduce performance and require withdrawal of horses. Yet, studies of the causes of pneumonia in horses are scant. This study aimed to describe the pathological and microbiological features of lung lesions in slaughtered horses in southern Brazil. In this study, 84 samples of lungs were examined, and a conclusive diagnosis was obtained in 74 cases. These were composed of bronchopneumonia in 50 cases, followed by granulomatous eosinophilic pneumonia $(9 / 74)$, recurrent airway obstruction $(7 / 74)$, lung fibrosis $(4 / 74)$, lung hemorrhage $(3 / 74)$ and pulmonary pythiosis $(1 / 74)$. Bronchopneumonia had grossly firm focally extensive yellow to dark-red areas, which consisted microscopically of multifocal to coalescing infiltrate of degenerate neutrophils. Streptococcus equi subsp. zooepidemicus was identified in 21 of the 50 cases. Granulomatous eosinophilic pneumonia had multifocal pinpoint firm-hard yellow areas, which microscopically were composed of granulomas with a mineralized center surrounded by collagen fibers and severe infiltrate of eosinophils. Recurrent airway obstruction had mild multifocal pinpoint firm white areas that consisted microscopically of large amounts of mucus inside bronchi and bronchiole. Lung fibrosis had two patterns: focally extensive areas of consolidation and firm nodular areas. Microscopically, the first pattern had interstitial to peribronchial fibrosis, while the second had, in addition to the interstitial fibrosis, a severe pneumocyte hyperplasia and an alveolar infiltrate of neutrophils and macrophages with rare intranuclear inclusion bodies (equine herpesvirus 5, EHV-5). Pulmonary pythiosis presented a focal firm nodular area, with multiple kunkers observed in the cut surface, which corresponded microscopically to areas of necrosis surrounded by a mixed inflammatory infiltrate. At the periphery of the necrotic areas, multiple negatively stained hyphae were observed, which were evidenced through Grocott's stain and immunohistochemistry anti-Pythium insidiosum.
\end{abstract}

INDEX TERMS: Lung lesions, slaughtered horses, Brazil, equine multinodular pulmonary fibrosis, granulomatous eosinophilic pneumonia, pneumonia, pythiosis, recurrent airway obstruction, Streptococcus equi, horses, pathology.

RESUMO.- [Lesões pulmonares de equinos de matadouro-frigorífico no Sul do Brasil.] Doenças respiratórias causam em equinos custos significativos com tratamento veterinário, redução de performance e descarte de animais. No entanto, estudos que abordem as causas de pneumonia em

\footnotetext{
${ }^{1}$ Received on August 2, 2018.

Accepted for publication on August 14, 2018.

${ }^{2}$ Setor de Patologia Veterinária, Faculdade de Veterinária, Universidade Federal do Rio Grande do Sul (UFRGS), Avenida Bento Gonçalves 9090, Agronomia, Porto Alegre, RS 91540-000, Brasil. E-mail: matheusviezzerb@hotmail.com; *Corresponding author: saulo.pavarini@ufrgs.br
}

equinos são escassos. 0 objetivo deste estudo foi descrever os aspectos patológicos e microbiológicos de lesões pulmonares em equinos abatidos em matadouro-frigorífico no Sul do Brasil. Neste estudo, 84 amostras de pulmões foram examinadas, e o diagnóstico conclusivo das condições foi obtido em 74 casos. Esses foram compostos por broncopneumonia em 50 casos, seguido por pneumonia granulomatosa eosinofílica $(9 / 74)$, obstrução aérea recorrente (7/74), fibrose pulmonar (4/74), hemorragia pulmonar $(3 / 74)$ e pitiose pulmonar $(1 / 74)$. A broncopneumonia era caracterizada macroscopicamente por áreas focalmente extensas firmes de coloração amarelada a 
vermelho-escuras, as quais consistiam microscopicamente em infiltrado multifocal a coalescente de neutrófilos degenerados. Streptococcus equi subsp. zooepidemicus foi identificado em 21 dos 50 casos. A pneumonia eosinofílica granulomatosa era caracterizada por áreas multifocais puntiformes firmes a duras e amareladas, que microscopicamente eram compostas por granulomas com área central mineralizada circundados por fibras de colágeno e infiltrado acentuado de eosinófilos. A obstrução aérea recorrente era caracterizada por discretas áreas puntiformes firmes e brancacentas que consistiam microscopicamente em grande quantidade de muco no interior de brônquios e bronquíolos. A fibrose pulmonar exibia dois padrões: áreas de consolidação focalmente extensas e áreas nodulares firmes. Microscopicamente, o primeiro padrão exibia fibrose intersticial a peribronquial, enquanto no segundo padrão havia, além da fibrose intersticial, intensa hiperplasia de pneumócitos e infiltrado alveolar de neutrófilos e macrófagos com raros corpúsculos de inclusão intranucleares (herpesvírus equino 5, EHV-5). A pitiose pulmonar exibia uma área nodular firme focal com múltiplos kunkers ao corte, os quais correspondiam microscopicamente a áreas de necrose circundadas por infiltrado inflamatório misto. À periferia das áreas necróticas, múltiplas imagens negativas de hifas eram observadas, as quais foram evidenciadas através da coloração de Grocott e imuno-histoquímica anti-Pythium insidiosum.

TERMOS DE INDEXAÇÃO: Lesões pulmonares, equinos, matadourofrigorífico, Brasil, fibrose pulmonar multinodular equina, pneumonia eosinofílica granulomatosa, pneumonia, pitiose, obstrução aérea recorrente, Streptococcus equi, patologia.

\section{INTRODUCTION}

Brazil has a horse population estimated at a total of 5.5 million animals, which encompasses the fourth largest population worldwide after United States, China and Mexico (FAO 2016). Horses in Rio Grande do Sul state compose the second largest population in Brazil, with approximately 537,159 animals (IBGE 2016), and are widely employed for handling cattle herds (Bianchi et al. 2016), for sports (Costa et al. 2014), and occasionally they are slaughtered for meat consumption. Horse meat consumption became popular in Europe after World War II, among people with lower incomes, since cattle beef was scarce (Padalino 2015).

Knowledge of diseases that occur in the equine species is crucial for determining its economic importance as well as the establishment of control procedures. Numerous studies described the causes of death in horses in the United States (USDA 2017), Europe (Baker \& Ellis 1981) and Brazil (Pierezan et al. 2009, Pereira et al. 2012, Marcolongo-Pereira et al. 2014). In these studies, the alimentary and locomotor systems were the most commonly affected (Baker \& Ellis 1981, Pierezan et al. 2009, Pereira et al. 2012, USDA 2017), while the respiratory system has been indicated as one of the five leading causes of death in horses (Baker \& Ellis 1981, Pierezan et al. 2009, Pereira et al. 2012, USDA 2017).

Respiratory diseases cause significant veterinary costs, reduce performance and require the withdrawal of racehorses (Wood et al. 2005, Carvallo et al. 2017). Bacterial pneumonia in foals is mainly caused by Rhodococcus equi and Escherichia coli (Lakritz et al. 1993), while in adult horses it has been associated to upper respiratory tract normal flora and opportunist pathogens that reach the lower respiratory tract, such as Streptococcus equi subsp. zooepidemicus and S. equi subsp. equi (Carvallo et al. 2017). Still, data for the causes of pneumonia in slaughtered horses have not yet been described.

This study aimed to describe the pathological and microbiological features of lung lesions observed in slaughtered horses in the southern Brazil, and to provide and discuss the differential diagnosis of these conditions.

\section{MATERIALS AND METHODS}

From January 2014 to December 2016, lung samples from adult horses (more than 5 years-old) submitted to slaughter were received refrigerated by the pathology laboratory for gross and histopathological analysis. Samples were collected at a slaughterhouse, which is located $350 \mathrm{~km}$ distant from the pathology laboratory in the municipality of

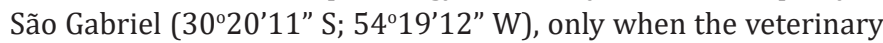
inspector of the abattoir had a suspicious of pneumonia due the presence of gross lesions, while respiratory clinical signs were not reported by the veterinary inspector. These samples were then sent refrigerated or frozen to the pathology laboratory, where the lung lesions were grossly described.

Bacterial culture was performed when a bacterial etiology was suspected and it consisted in the inoculation of tissue fragments and purulent contents in Blood agar plates (5\% sheep blood, Mueller Hinton, Kasvi $^{\circledR}$, Brazil) and MacConkey agar (Kasvi ${ }^{\circledR}$, Brazil) followed by aerobic incubation at $37^{\circ} \mathrm{C}$ for 72 hours. Streptococcus equi subsp. zooepidemicus, Streptococcus equi subsp. equi and S. equi subsp. ruminatorum were identified by Gram staining, microscopic appearance, and by epidemiology, cultural and biochemical characteristics (Table 1) (Fernández et al. 2004, Markey et al. 2013).

Samples were fixed in 10\% neutral buffered formalin for $24-48 \mathrm{~h}$, trimmed, processed routinely for histopathology and stained by hematoxylin and eosin (HE). Microscopically, when a granulomatous response was observed, the slides were submitted to the Ziehl-Neelsen (ZN) histochemistry exam, in addition to Grocott's methenamine silver (GMS) stain to evidence fungal structures. Cases of recurrent airway obstruction were submitted to alcian blue stain. In the cases where fibrosis was microscopically observed, tissue sections were submitted to Masson's trichrome stain.

Fungal-suspected cases were submitted to the immunohistochemistry anti-Pythium insidiosum, according to a protocol previously described (Konradt et al. 2016) with a polyclonal antibody. The reaction was revealed with 3-amino-9-ethylcarbazole (AEC; Biocare Medical, Pacheco/CA, USA), followed by counterstaining with Harris hematoxylin.

\section{RESULTS}

From January 2014 to December 2016, 84 samples of lungs (containing 1 to 2 lung lobules) from slaughtered horses were examined. Horses slaughtered in this slaughterhouse were originated from multiple sites in the state and from the neighboring state of Santa Catarina, with a maximum travel distance of $750 \mathrm{~km}$. A conclusive diagnosis was obtained in 74 cases, which were mainly composed of suppurative inflammation involving the bronchi, bronchioles and alveolar spaces (bronchopneumonia; 50/74), followed by granulomatous eosinophilic pneumonia $(9 / 74)$, recurrent airway obstruction $(7 / 74)$, lung fibrosis $(4 / 74)$, lung hemorrhage $(3 / 74)$ and pulmonary pythiosis $(1 / 74)$. 


\section{Suppurative bronchopneumonia}

Grossly, the lungs with suppurative inflammation had firm (36/50) focally extensive to multifocal yellow $(24 / 36)$ to dark-red (17/36) (Fig.1A,B) areas in addition to purulent content within the bronchi $(22 / 36)$, occasionally extending to the parenchyma $(7 / 36)$. Microscopically, a moderate to intense multifocal to coalescing inflammatory infiltrate of degenerate neutrophils involving the bronchi $(36 / 50)$,

Table 1. Biochemical characteristics useful in distinguishing Streptococcus equi subsp. equi from S. equi subsp. zooepidemicus and $S$. equi subsp. ruminatorum

\begin{tabular}{|c|c|c|c|}
\hline \multirow{2}{*}{ Test } & \multicolumn{3}{|c|}{ Strain } \\
\hline & S. equi subsp. equi & S. equi subsp. zooepidemicus & S. equi subsp. ruminatorum \\
\hline CAMP reaction & - & - & + \\
\hline Hydrolysis of hippurate & - & - & + \\
\hline Hydrolysis of esculin & - & - & - \\
\hline \multicolumn{4}{|l|}{ Production of acid from: } \\
\hline Sorbitol & - & + & - \\
\hline Trehalose & - & - & - \\
\hline Lactose & - & + & + \\
\hline Ribose & - & + & + \\
\hline Maltose & + & $+(-)$ & + \\
\hline Sucrose & + & + & - \\
\hline
\end{tabular}
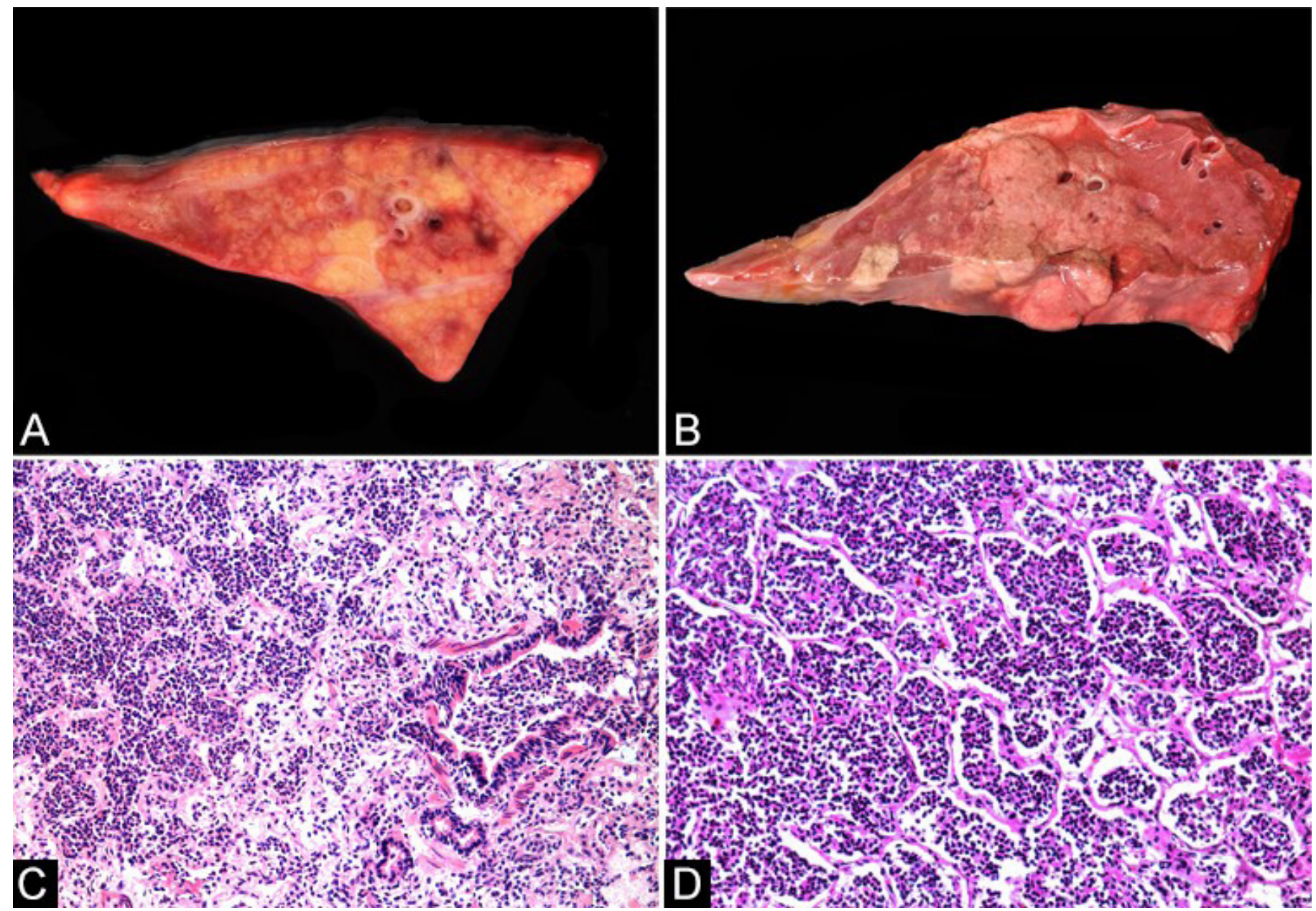

Fig.1. Suppurative inflammation involving the bronchi, bronchioles and alveolar spaces (bronchopneumonia) in slaughtered horses.

(A-B) The lungs had focally extensive to multifocal yellow to dark-red areas in the parenchyma. (C) Intense multifocal to coalescent infiltrate of degenerate neutrophils involving the bronchioli and alveolar spaces. HE, obj.10x. (D) Severe infiltrate of neutrophils in the alveolar spaces. HE, obj.20x. 
bronchioles (48/50) and alveolar spaces (40/50) characterized these lesions (Fig.1C,D), in addition to occasional coccoid bacterial myriad mainly in the bronchi $(11 / 50)$ and a severe and diffuse alveolar edema (32/50), which rarely involved the lobular septum (7/50). The suppurative infiltrate was often accompanied by fibrin deposition in the alveolar spaces $(32 / 50)$, occasionally by interstitial fibrosis (11/50) and rarely by areas of intra-alveolar hemorrhage (3/50).

Lung suppurative processes involved a bacterial cause in 26 cases $(26 / 50)$. Strains showing beta-hemolytic mucoid colonies (1-3 mm in diameter), with gram-positive spherical or ovoid cocci in pairs or chains, that were catalase-negative, with no growth in $6.5 \% \mathrm{NaCl}$ were identified as $S$. equi. According to the biochemical characteristics available in Table 1,21 isolates were identified as Streptococcus equi subsp. zooepidemicus, followed by $S$. equi subsp. equi $(2 / 26)$, and $S$. equi subsp. ruminatorum $(1 / 26)$. The identification of two strains was not possible through cultural and biochemical methods, and, thus, these were identified as ß-hemolytic Streptococcus spp.

\section{Granulomatous eosinophilic pneumonia}

Granulomatous eosinophilic pneumonia was grossly characterized in all cases by multifocal pinpoint firm to hard yellow areas $(0.1-0.3 \mathrm{~cm}$ in diameter) involving mainly the lung parenchyma and occasionally the pleura (Fig.2A).
Microscopically, these pinpoint areas had a central area of dystrophic mineralization surrounded by abundant collagen fibers, occasional epithelioid macrophages and foreign body-type multinucleated giant cells. At the periphery of these, there was a severe inflammatory infiltrate mainly composed of eosinophils, with a few plasma cells and lymphocytes (Fig.2B). The lumen of bronchi and bronchioli was filled by an amorphous amphophilic material intermixed by an intense inflammatory infiltrate of eosinophils. At the ZN and GMS, neither acid-fast bacilli nor fungi were identified. No bacterial agent was obtained through aerobic culture.

\section{Recurrent airway obstruction}

Recurrent airway obstruction (RAO) was characterized grossly by non-collapsed areas in the lung, which on the cut surface showed multifocal discrete pinpoint firm white areas with accumulation of mucopurulent content inside bronchi $(7 / 74)$. Histologically, bronchi and bronchioles contained in the lumen large amounts of an amphophilic amorphous material (mucus) intermixed by a mild inflammatory infiltrate of eosinophils and the mucosa was often hyperplastic with large numbers of goblet cells (metaplasia) (Fig.2C). The smooth muscle of these bronchi and bronchioles was variably hypertrophic. Alcian blue histochemistry exam evidenced the mucus in the
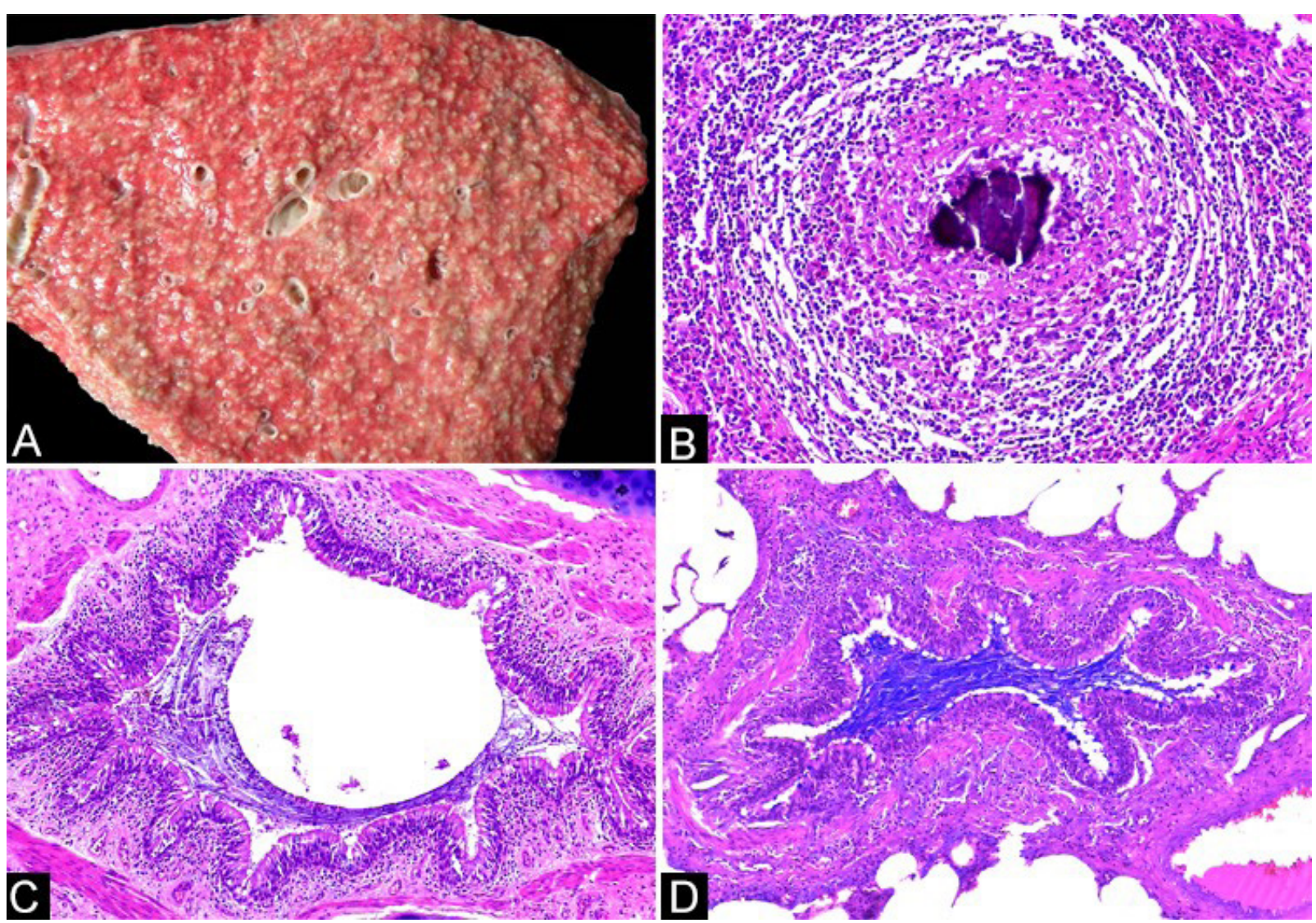

Fig.2. (A-B) Granulomatous eosinophilic pneumonia and (C-D) recurrent airway obstruction in slaughtered horses. (A) Multifocal pinpoint yellow areas (0.1-0.3 cm in diameter) involving the lung parenchyma. (B) Microscopically these had a central area of mineralization surrounded by collagen fibers and occasional epithelioid macrophages, and at the periphery large numbers of eosinophils. HE, obj.20x. (C) Mucus filled the lumen of bronchi and the mucosa was hyperplasic. HE, obj.10x. (D) Mucus in the lumen and increased numbers of goblet cells in the mucosa of this bronchiole were evidenced. Alcian blue stain, obj.10x. 
lumen of the bronchi and bronchioli, in addition to the large numbers of Goblet cells in the mucosa (Fig.2D).

\section{Lung fibrosis}

Lung fibrosis occurred in two distinct gross and microscopic patterns. The first one involved two cases and was grossly characterized by focally extensive whitish poorly limited areas of lung consolidation. Microscopically, these cases had interstitial to peribronchial fibrosis, in addition to moderate infiltrate of macrophages containing a brown granular pigment in the cytoplasm (hemosiderosis) in the alveolar septum. The second pattern occurred in two cases and was grossly characterized by a firm and whitish nodular area in each case, which measured $8 \times 5 \times 4 \mathrm{~cm}$ and $4 \times 3 \times 2 \mathrm{~cm}$, and, on the cut surface, it was outlined by a red halo from the remaining of the lung parenchyma in one of the cases (Fig.3A). Microscopically, both cases had moderate to severe interstitial fibrosis and a severe type II pneumocyte hyperplasia in the alveolar spaces, which was associated to a moderate inflammatory infiltrate of degenerate neutrophils, macrophages and rare multinucleated giant cells. Multiple basophilic and round intranuclear inclusion bodies were observed in the macrophages in one of these cases (Fig.3B) and, thus, this was compatible with equine multinodular pulmonary fibrosis (EMPF) caused by equine herpesvirus 5 (EHV-5). Masson's trichrome stain evidenced the interstitial fibrosis in all cases.

\section{Lung hemorrhage}

Grossly, lungs with hemorrhage were reddened on gross examination, while microscopically there was a moderate to severe diffuse hemorrhage in the alveolar spaces $(3 / 3)$, occasionally associated to a multifocal infiltrate of macrophages containing granular brownish pigment (hemosiderosis) in the alveolar septum $(1 / 3)$.

\section{Pulmonary pythiosis}

Pulmonary pythiosis corresponded to a focal nodular and firm area in the lung parenchyma, measuring $11 \times 9 \times 5 \mathrm{~cm}$. On the cut surface, this nodular area had multifocal to coalescing yellow, irregular, firm, but friable masses (compatible with "kunkers"), which were surrounded by a moderate red halo and outlined by a thick white tissue (capsule) (Fig.3C). Microscopically, these consisted of multifocal to coalescing nodular structures which contained a central amorphous eosinophilic necrotic material surrounded by a marked inflammatory infiltrate of neutrophils, eosinophils, epithelioid macrophages and Langhans-type multinucleated giant cells, in addition to severe fibrous tissue proliferation. At the periphery of the necrotic
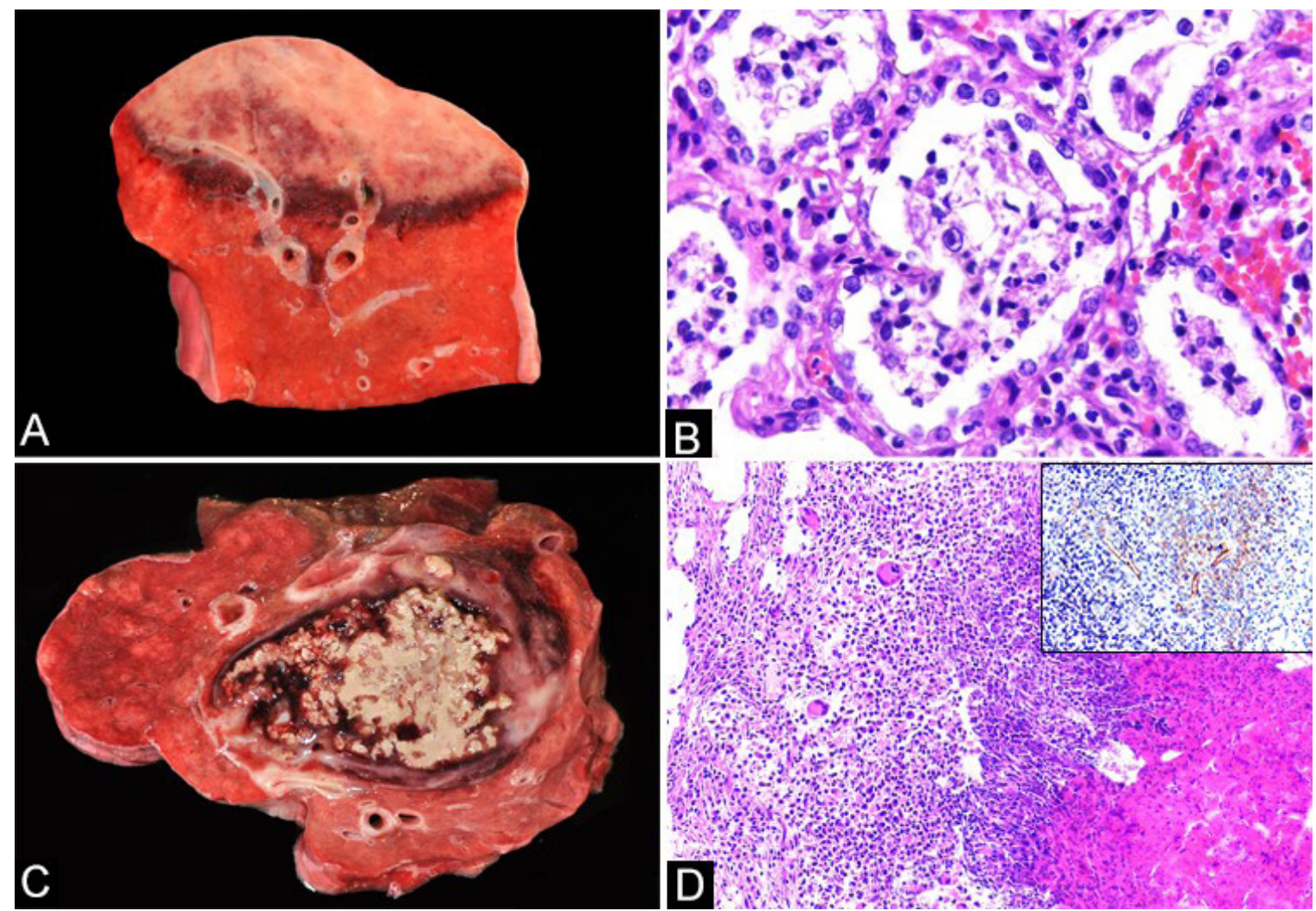

Fig.3. (A-B) Equine multinodular pulmonary fibrosis (EMPF) and (C-D) pulmonary pythiosis. (A) Focally extensive whitish nodule outlined by a red halo in the lung parenchyma. (B) Alveolar spaces had severe pneumocyte hyperplasia associated to infiltrate of degenerate neutrophils and macrophages, often containing intranuclear inclusion bodies (suggestive of EHV-5; arrow). HE, obj.40x. (C) Pythiosis corresponded to a focal nodule that on the cut surface had multifocal to coalescing "kunkers". (D) Microscopically, these had a central eosinophilic necrosis surrounded by a marked inflammatory infiltrate of neutrophils, eosinophils, epithelioid macrophages and Langhans-type multinucleated giant cells. Negatively stained sections of hyphae were observed at the periphery of the necrotic areas. HE, obj.10x. Inset: marked immunostaining of hyphae within the "kunkers". Immunohistochemistry anti-Pythium insidiosum. AEC, obj.40x. 
areas, multiple negatively stained transverse and longitudinal sections of hyphae were observed (Fig.3D). Sections of lung stained by GMS evidenced abundant branching, rarely septate and 5- $\mu \mathrm{m}$-in-diameter irregular hyphae, which were also stained by IHC for P. insidiosum (Fig.3D inset).

\section{DISCUSSION}

The diagnosis in all cases was obtained by the association of the gross, microscopical, immunohistochemical, histochemical and bacteriological features. Our findings indicated that suppurative bronchopneumonia was the main lung lesion in slaughtered horses. Primary pneumonia in adult horses may happen due to stressful events, such as transportation and long distance travel (Mair \& Lane 1989), as we have observed in this study. Stress may predispose lower respiratory tract infection in horses by impairing the pulmonary defense mechanisms (Bayly et al. 1986), and, thereby, it facilitates colonization by Streptococcus equi subsp. zooepidemicus, which is considered an upper respiratory tract commensal bacterium. Still, it is one of the most frequently isolated bacterial pathogen of young (Lakritz et al. 1993) and adult horses (Bailey \& Love 1991). Since horses of the present study were transported for long distances with variable duration of trips, we speculated that these were the main predisposing factors for the lesions observed. S. equi subsp. zooepidemicus was identified in 21 cases, followed by $S$. equi subsp. equi in two cases. When these pathogens are compared, $S$. equi subsp. zooepidemicus has a broader tissue tropism (Carvallo et al. 2017), being able to infect, in addition to the lungs, other reproductive organs (Erol et al. 2012). On the other hand, S. equi subsp. equi, the etiologic agent of strangles, predominantly involves the upper airways and associated lymph nodes with abscess formation, but spread to other organs may occur in "bastard strangles" through blood, lymphatic or aspiration of pus into the lungs (Timoney 2004, Caswell \& Williams 2016), with the development of necrotizing pneumonia. In this study, however, both $S$. equi subsp. zooepidemicus and S. equi subsp. equi most likely spread through the airway system, affecting the lower respiratory tract with a suppurative bronchopneumonia. This lesion distribution is consistent with inhalation of aerolised bacteria and has been referred as acentric-acinar, corresponding, grossly, to well-defined areas of dark red consolidation (Oikawa et al. 1995, Racklyeft \& Love 2000). Still, further evaluation of the pathogenesis of the condition was compromised by the lack of all lung lobes in the samples analyzed. A bacterial agent was not obtained in 24 cases, yet the gross and microscopical lesions were characteristic of a bacterial cause. However, culture may be unsuccessful during the incubation and early clinical phases of the condition (Timoney 2004).

Fibrosing granulomas involving the lungs were initially described as primary lesions of the liver and peritoneum of horses, and were grossly characterized by numerous firm and gritty nodules (Buergelt \& Greiner 1995), similarly to the ones observed in the present study. Likewise, similar gross lesions in the lungs without systemic involvement have been described in horses, being referred as idiopathic eosinophilic pneumonia or disseminated eosinophilic pulmonary granulomas (Uhlhorn et al. 2006, Bell et al. 2008, Magi et al. 2016). Since lesions observed in the present study were both gross and microscopically similar to these studies, the condition was referred as granulomatous eosinophilic pneumonia, which was the second most common condition involving the lungs of slaughtered horses. Microscopically, the granulomas of the present study had large amounts of dense fibrous tissue, epithelioid macrophages and multinucleated giant cells surrounding a necrotic or mineralized center, and at the periphery there was a severe inflammatory infiltrate of eosinophils, corroborating with previous findings (Uhlhorn et al. 2006), but it differed from another description of associated vascular lesions (Magi et al. 2016).

After extensive search for parasitary structures in the lesions, these were absent. Previous studies have also failed to identify the cause of these lesions in the lungs (Buergelt \& Greiner 1995, Uhlhorn et al. 2006, Magi et al. 2016). Yet, we believe that these were initially caused by a parasite migration, considering that while the chronic reaction progresses, the dead eggs or larvae may disappear through degeneration and calcification in these lesions (Buergelt \& Greiner 1995). Migrating helminths parasites, as Parascaris equorum or Dictyocaulus arnfield, are possible causes of these lesions (Nicholls et al. 1978, Mackay \& Urquhart 1979). Yet, the larvae of $P$. equorum usually undergo pulmonary migration when horses are young (Bell et al. 2008), whilst the horses of the present study were all adults, and the lesions are usually transitory (Nicholls et al. 1978). On the other hand, Dictyocaulus arnfieldi causes eosinophilic bronchitis in adult horses (Mackay \& \& Urquhart 1979), which was not observed in the present study. Heterobilharzia americana, a schistosome that causes canine schistosomiasis in the USA, is able to cause a similar granulomatous and eosinophilic pneumonia in llamas and horses, but is mostly an hepatic disease (Buergelt \& Greiner 1995, Corapi et al. 2012, 2015). Still, this parasite has not been reported in Brazil, neither have the characteristic eggs and empty eggshells been observed in the center of the granulomas in the present study.

Granulomatous and eosinophilic lesions in the lungs of horses should be differentiated mainly from Mycobacterium spp. infections, fungi infections (Buergelt \& Greiner 1995), multisystemic eosinophilic epitheliotropic disease (MEED), eosinophilic bronchiolitis and parasitic bronchopneumonia (Bell et al. 2008, Magi et al. 2016). Mycobacterium spp. and fungi infections were ruled out in these cases based on the absence of staining through ZN and GMS, as reported previously (Buergelt \& Greiner 1995, Uhlhorn et al. 2006, Magi et al. 2016), as well as by the marked eosinophilic infiltrate, which are not typical of these conditions (Uhlhorn et al. 2006). MEED typically affects young horses (Uhlhorn et al. 2006), while the horses of the present study were all adults, and significant involvement of the respiratory tract is uncommon (Pucheu-Haston \& Del Piero 2013).

RAO or "heaves" is an inflammatory airway disease of mature horses (Caswell \& Williams 2016), formerly known as chronic obstructive pulmonary disease (Buergelt \& Del Piero 2014). Similarly to the observed in the present study, the most characteristic gross lesions of this condition in horses are the lack of pulmonary collapse (Buergelt \& Del Piero 2014) and the accumulation of mucopurulent secretions throughout the tracheobronchial tree (Pirie 2014). Lesions are usually more severe in the caudodorsal lung (Caswell \& Williams 2016); however, since only fragments of lung lobes were evaluated in this study, this focal involvement was not analyzed, as well as 
the clinical importance of this lesion may not be extrapolated from these cases. Microscopically, this condition presents the accumulation of mucus and neutrophils in bronchiolar lumens and hyperplasia of goblet cells (Caswell \& Williams 2016), which were observed in all horses, in addition to a variable peribronchial and peribronchioli smooth muscle hypertrophy (Caswell \& Williams 2016), which may explain the gross pinpoint white firm areas, as previously described (Buergelt \& Del Piero 2014).

Interstitial lung fibrosis is a proliferative response to the damage of the alveolar walls and loss of functional alveolar-capillary in horses. A specific cause for this condition may not be recognized (Buergelt et al. 1986), as in three of the four cases in this study. Interstitial lung fibrosis was identified in six horses in a retrospective study in Brazil (Estima-Silva et al. 2017), which were microscopically similar to all the four cases described in the present study. In older horses, this condition may result in interalveolar septal thickening by fibrosis, in addition to fibrosis in the visceral pleura (Buergelt et al. 1986). This pattern of lesion was observed in two of the horses of the present study, while in the other two cases we observed a preservation of the "alveolar-like" architecture with the lumen of the alveoli delineated by type II pneumocyte hyperplasia, which have been described as characteristic of EMPF (Williams et al. 2007). This is a chronic infectious disease caused by EHV-5 in adult horses, which forms numerous coalescing nodules in the lungs (Williams et al. 2007). This condition has been previously described in Brazil in two horses (Panziera et al. 2014, Estima-Silva et al. 2017), and in this study a suggestive diagnosis of EMPF by EHV-5 in one of the cases was obtained by the association of the gross and the microscopic features. Similarly to the previously described changes in a race horse, the multiple intranuclear inclusion bodies associated to the interstitial fibrosis are characteristic of this condition (Williams et al. 2007, Carvallo et al. 2017). The histological features of EMPF are distinct from other causes of fibrosis (Williams et al. 2007), as it was observed in the remaining two cases of interstitial fibrosis, in which a specific cause could not be determined.

Pythiosis is a tropical to subtropical disease caused by Pythium insidiosum that mostly affects horses (Mendoza et al. 1996), and lesions are usually cutaneous to subcutaneous (Souto et al. 2016). This condition is considered endemic in the Brazilian Pantanal (Leal et al. 2001) and in the Rio Grande do Sul state (Weiblen et al. 2016). Pulmonary pythiosis has been described in a Panthera onca (Camus et al.2004) and in horses (Goad 1984, Reis Junior et al. 2003, Souto et al. 2016), being mainly associated to the inhalation of the agent in water and/or ingestion with subsequent aspiration of infective material (Goad 1984). It is possible that the lesion observed was associated to a nasal infection, since it has been reported previously in horses (Reis Junior et al. 2003, Vaz et al. 2009, Galiza et al. 2014, Souto et al. 2016), but grossly the origin of this lesion was not determined. In addition to that, some authors have described previous cutaneous lesions that would allow the hematogenous dissemination of the pathogen to internal organs, such as the lungs, through detached hyphal segments of $P$. insidiosum (Reis Junior et al. 2003). This form of dissemination would lead to a multifocal distribution of these lesions (Goad 1984, Reis Junior et al. 2003), and seems less likely considering that the focal nodular was isolated from the remaining parenchyma. Sequestra in the lungs, which commonly develops with masses of necrotic lung parenchyma (Caswell \& Williams 2016), has been described in a case of lung pythiosis in a horse (Goad 1984), similarly to the present case, suggesting that the response of the organism may be effective in isolating the lesion. On the other hand, the presence of "kunkers" seems to be a constant finding in horses both in cutaneous, nasal, alimentary and pulmonary lesions (Goad 1984, Reis Junior et al. 2003, Martins et al. 2012, Souto et al. 2016). Microscopical lesions were similar to those observed in nasal and lung lesions (Goad 1984, Souto et al. 2016), but distinct from cutaneous or subcutaneous lesions, in which an eosinophilic dermatitis associated with the formation of granulation tissue predominates (Martins et al. 2012). The gross and microscopic lesions, in addition to the immunohistochemical features observed, were characteristic of the condition, and allowed us to differentiate it from Conidiobolus spp. and Basidiobolus spp. infections, as previously described (Reis Junior et al. 2003).

\section{CONCLUSIONS}

Bacterial bronchopneumonia caused by Streptococcus equi subsp. zooepidemicus is the main cause of lung lesions in slaughtered horses.

No etiological agent was detected in granulomatous eosinophilic pneumonia cases, although microscopically these were characteristic of parasite induced lesions with a mineralized center surrounded by collagen and large numbers of eosinophils at the periphery.

Recurrent airway obstruction had mild gross lesions, while microscopically it presented an accumulation of mucus and eosinophils in the airways associated to hyperplasia of the epithelium and goblet cells.

Lung interstitial fibrosis was mostly of unknown cause, while in one of the cases the lesion was characteristic of EMPF caused by EHV-5.

Lung pythiosis occurred in one horse and shared similar gross and microscopic features to cutaneous, alimentary and nasal pythiosis. Immunohistochemistry is essential for pythiosis diagnosis in the absence of culture.

Conflict of interest statement.- The authors have no competing interests.

Animal welfare/ethical statement.- We authors of the article entitled "Lung lesions of slaughtered horses in Southern Brazil" declared, for all due purposes, the project that gave rise to the present data of this manuscript has been submitted for evaluation to the Ethics Committee of the Universidade Federal do Rio Grande do Sul (UFRGS), and has been approved under the number 33501 at December 7th, 2017.

Acknowledgements.- We thank DVM Neide Severo for all the support in sending the lung samples for analysis to the veterinary pathology laboratory. We thank Conselho Nacional de Desenvolvimento Científico e Tecnológico (CNPq) and Coordenação de Aperfeiçoamento de Pessoal de Nível Superior (CAPES) to support this study.

\section{REFERENCES}

Bailey G.D. \& Love D.N. 1991. Oral associated bacterial infection in horses: studies on the normal anaerobic flora from the pharyngeal tonsillar surface and its association with lower respiratory tract and paraoral infections. 
Vet. Microbiol. 26(4):367-379. <http://dx.doi.org/10.1016/03781135(91)90030-J> <PMid:2031304>

Baker J.R. \& Ellis C.E. 1981. A survey of post mortem findings in 480 horses 1958 to 1980: causes of death. Equine Vet. J. 13(1):43-46. <http://dx.doi. org/10.1111/j.2042-3306.1981.tb03448.x><PMid:7238480>

Bayly W.M., Liggit H.D., Huston L.J. \& Laegreid W.W. 1986. Stress and its effect on equine pulmonary mucosal defenses. Proc. Am. Assoc. Equine Pract. 32:253-262.

Bell S.A., Drew C.P., Wilson W.D. \& Pusterla N. 2008. Idiopathic chronic eosinophilic pneumonia in 7 horses. J. Vet. Intern. Med. 22(3):648-653. <http://dx.doi.org/10.1111/j.1939-1676.2008.0100.x><PMid:18466259>

Bianchi M.V., Boos G.S., Mello L.S., Vargas T.P., Sonne L., Driemeier D. \& Pavarini S.P. 2016. A retrospective evaluation of equine cutaneous lesions diagnosed in Southern Brazil. Acta Scient. Vet. 44:1388.

Buergelt C.D. \& Greiner E.C. 1995. Fibrosing granulomas in the equine liver and peritoneum: a retrospective morphologic study. J. Vet. Diagn. Invest. 7(1):102-107. <http://dx.doi.org/10.1177/104063879500700117> $<$ PMid:7779944>

Buergelt C.D. \& Del Piero F. 2014. Color Atlas of Equine Pathology. John Wiley and Sons, Ames, p.115-116.

Buergelt C.D., Hines S.A., Cantor G., Stirk A. \& Wilson J.H. 1986. A retrospective study of proliferative interstitial lung disease of horses in Florida. Vet. Pathol. 23(6):750-756. <http://dx.doi.org/10.1177/030098588602300614> $<$ PMid:3811140>

Camus A.C., Grooters A.M. \& Aquilar R.F. 2004. Granulomatous pneumonia caused by Pythium insidiosum in a central American jaguar Panthera onca. J. Vet. Diagn. Invest. 16(6):567-571. <http://dx.doi.org/10.1177/104063870401600612> $<$ PMid:15586573>

Carvallo F.R., Uzal F.A., Diab S.S., Hill A.E. \& Arthur R.M. 2017. Retrospective study of fatal pneumonia in racehorses. J. Vet. Diagn. Invest. 29(4):450-456. <http://dx.doi.org/10.1177/1040638717717290 > PMid:28681687>

Caswell J.L. \& Williams K.J. 2016. Respiratory system, p.465-591. In: Maxie M.G. (Ed.), Jubb, Kennedy and Palmer's Pathology of Domestic Animals. 6th ed. Vol 2. Elsevier Saunders, St Louis. <http://dx.doi.org/10.1016/ B978-0-7020-5318-4.00011-5>.

Corapi W.V., Eden K.B., Edwards J.F. \& Snowden K.F. 2015. Heterobilharzia americana infection and congestive heart failure in a llama (Lama glama). Vet. Pathol. 52(3):562-565. <http://dx.doi.org/10.1177/0300985814540541> <PMid:24964922>

Corapi W.V., Snowden K.F., Rodrigues A., Porter B.F., Buote M.A., Birch S.M., Jackson N.D., Eden K.B., Whitley D.B., Mansell J., Edwards J.F., Hardy J. \& Chaffin M.K. 2012. Natural Heterobilharzia americana infection in horses in Texas. Vet. Pathol. 49(3):552-556. <http://dx.doi.org/10.1177/0300985811432346> $<$ PMid:22273574>

Costa E., Diehl G.N., Santos D.V. \& Silva A.P.S. 2014. Panorama da equinocultura no Rio Grande do Sul. Informativo Técnico 5, Departamento de Defesa Agropecuária, Secretaria da Agricultura, Pecuária e Irrigação, Rio Grande do Sul.

Erol E., Locke S.J., Donahoe J.K., Mackin M.A. \& Carter C.N. 2012. Beta-hemolytic Streptococcus spp. from horses: a retrospective study (2000-2010). J. Vet. Diagn. Invest. 24(1):142-147. <http://dx.doi.org/10.1177/1040638711434138> <PMid:22362945>

Estima-Silva P., Marcolongo-Pereira C., Santos B.L., Coelho A.C.B., Amaral L.A., Lim A., Bolin S.R. \& Schild A.L. 2017. Equine multinodular pulmonary fibrosis in southern Brazil: pathology and differential diagnosis. Pesq. Vet. Bras. 37(11):1247-1252. <http://dx.doi.org/10.1590/s0100736x2017001100009>

FAO 2016. Data of live animals: horses. Food and Agriculture Organization of the United Nations. Available at <http://www.fao.org/faostat/en/\#data/ QA> Access on Mar. 19, 2018.
Fernández E., Blume V., Garrido P., Collins M.D., Mateos A., Domínguez L. \& Fernández-Garayzábal J.F. 2004. Streptococcus equi subsp. ruminatorum subsp. nov., isolated from mastitis in small ruminants. Int. J. Syst. Evol. Microbiol. 54(6):2291-2296. <http://dx.doi.org/10.1099/ijs.0.63145-0> $<$ PMid:15545473>

Galiza G.J.N., Silva T.M., Caprioli R.A., Barros C.S.L., Irigoyen L.F., Fighera R.A., Lovato M. \& Kommers G.D. 2014. Ocorrência de micoses e pitiose em animais domésticos: 230 casos. Pesq. Vet. Bras. 34(3):224-232. http:// dx.doi.org/10.1590/S0100-736X2014000300005.

Goad M.E.P. 1984. Pulmonary pythiosis in a horse. Vet. Pathol. 21(2):261-262. <http://dx.doi.org/10.1177/030098588402100224><PMid:6730214>

IBGE 2016. Tabela 3939: efetivo dos rebanhos por tipo de rebanho. Instituto Brasileiro de Geografia e Estatística, Brasília, DF. Available at <https:// sidra.ibge.gov.br/Tabela/3939\#resultado> Accessed on Mar. 19, 2018.

Konradt G., Bassuino D.M., Bianchi M.V., Castro L., Caprioli R.A., Pavarini S.P., Santurio J.M., Azevedo M.I., Jesus F.P. \& Driemeier D. 2016. Cutaneous pythiosis in calves: An epidemiologic, pathologic, serologic and molecular characterization. Med. Mycol. Case Rep. 14:24-26. <http://dx.doi. org/10.1016/j.mmcr.2016.11.004><PMid:28050341>

Lakritz J., Wilson W.D., Berry C.R., Schrenzel M.D., Carlson G.P. \& Madigan J.E. 1993. Bronchointerstitial pneumonia and respiratory distress in young horses: clinical, clinicopathologic, radiographic, and pathological findings in 23 cases (1984-1989). J. Vet. Intern. Med. 7(5):277-288. <http://dx.doi. org/10.1111/j.1939-1676.1993.tb01020.x><PMid:8263846>

Leal A.B.M., Leal A.T., Santurio J.M., Kommers G.D. \& Catto J.B. 2001. Equine pythiosis in the Brazilian Pantanal region: Clinical and pathological findings of typical and atypical cases. Pesq. Vet. Bras. 21(4):151-156.<http://dx.doi. org/10.1590/S0100-736X2001000400005>

Mackay R.J. \& Urquhart K.A. 1979. An outbreak of eosinophilic bronchitis in horses possibly associated with Dictyocaulus arnfieldi infection. Equine Vet. J. 11(2):110-112. <http://dx.doi.org/10.1111/j.2042-3306.1979. tb01320.x $><$ PMid:157874>

Magi G.E., Mari S., Mariotti F. \& Rossi G. 2016. Idiopathic eosinophilic pneumonia with associated pulmonary vasculitis in horse: a case series Vet. Med. Open J.1(1):18-21. <http://dx.doi.org/10.17140/VMOJ-1-104>

Mair T.S. \& Lane J.G. 1989. Pneumonia, lung abscesses and pleuritis in adult horses: a review of 51 cases. Equine Vet. J. 21(3):175-180. <http://dx.doi. org/10.1111/j.2042-3306.1989.tb02135.x><PMid:2731504>

Marcolongo-Pereira C., Estima-Silva P., Soares M.P., Sallis E.S.V., Grecco F.B., Raffi M.B., Fernandes C.G. \& Schild A.L. 2014. Equine diseases in Southern Brazil. Pesq. Vet. Bras. 34(3):205-210. <http://dx.doi.org/10.1590/S0100736X2014000300002>

Markey B., Leonard F., Archambault M., Cullinane A. \& Maguire D. 2013. The streptococci and related cocci, p.121-134. In: Markey B., Leonard F., Archambault M., Cullinane A. \& Maguire D. (Eds), Clinical Veterinary Microbiology. 2nd ed. Mosby Elsevier, USA.

Martins T.B., Kommers G.D., Trost M.E., Inkelmann M.A., Fighera R.A. \& Schild A.L. 2012. A comparative study of the histopathology and immunohistochemistry of pythiosis in horses, dogs and cattle. J. Comp. Path. 146(2/3):122-131. <http://dx.doi.org/10.1016/j.jcpa.2011.06.006><PMid:21824626>

Mendoza L., Ajello L. \& McGinnis M.R. 1996. Infections caused by the oomycetous pathogen Pythium insidiosum. J. Med. Mycol. 6(4):151-164.

Nicholls J.M., Clayton H.M., Pirie H.M. \& Duncan J.L. 1978. A pathological study of the lungs of foals infected experimentally with Parascaris equorum. J. Comp. Pathol. 88(2):261-274. <http://dx.doi.org/10.1016/00219975(78)90030-0><PMid:659680>

Oikawa M., Takagi S., Anzai R., Yoshikawa H. \& Yoshikawa T. 1995. Pathology of equine respiratory disease occurring in association with transport. J. Comp. Pathol. 113(1):29-43. <http://dx.doi.org/10.1016/S00219975(05)80066-0><PMid:7490335> 
Padalino B. 2015. Effects of the different transport phases on equine health status, behavior, and welfare: a review. J. Vet. Behav. 10(3):272-282. <http:// dx.doi.org/10.1016/j.jveb.2015.02.002>

Panziera W., Giaretta P.R., Galiza G.J.N., Lim A., Bolin S.R., Borges C.H., Fighera R.A. \& Barros C.S.L. 2014. Equine multinodular pulmonary fibrosis associated with equine hespesvirus 5 in a horse in Brazil. Braz. J. Vet. Pathol. 7(1):17-20.

Pereira M.C., Ferraz G.C., Ferraudo A.S., Quintelas A.R., Berkman C. \& QueirozNeto A. 2012. Causes of death of Thoroughbred racehorses at Octavio Dupont Veterinary Hospital, Brazilian Jockey Club, Rio de Janeiro. Pesq. Vet. Bras. 32(3):189-193.

Pierezan F., Rissi D.R., Rech R.R., Fighera R.A., Brum J.S. \& Barros C.S.L. 2009. Necropsy findings related to the cause of death in 335 horses: 1968-2007. Pesq. Vet. Bras. 29(3):275-280. <http://dx.doi.org/10.1590/S0100736X2009000300015>

Pirie R.S. 2014. Recurrent airway obstruction: a review. Equine Vet. J. 46(3):276-288. <http://dx.doi.org/10.1111/evj.12204><PMid:24164473>

Pucheu-Haston C.M. \& Del Piero F. 2013. Equine multi-systemic eosinophilic epitheliotropic disease. Equine Vet. Educ. 25(12):614-617. <http://dx.doi. org/10.1111/eve.12107>

Racklyeft D.J. \& Love D.N. 2000. Bacterial infection of the lower respiratory tract in 34 horses. Aust. Vet. J. 78(8):549-559. <http://dx.doi. org/10.1111/j.1751-0813.2000.tb11901.x> <PMid:10979512>

Reis Junior J.L.J., Carvalho E.C.Q., Nogueira R.H.G., Lemos L.S. \& Mendoza L. 2003. Disseminated pythiosis in three horses. Vet. Microbiol. 96(3):289-295. <http://dx.doi.org/10.1016/j.vetmic.2003.07.005><PMid:14559176>

Souto E.P.F., Maia L.A., Olinda R.G., Galiza G.J.N., Kommers G.D., Miranda-Neto E.G., Dantas A.F.M. \& Riet-Correa F. 2016. Pythiosis in the nasal cavity of horses. J. Comp. Pathol. 155(2/3):126-129. <http://dx.doi.org/10.1016/j. jсpa.2016.06.005> <PMid:27406311>

Timoney J.F. 2004. The pathogenic equine streptococci. Vet. Res. 35(4):397409. <http://dx.doi.org/10.1051/vetres:2004025><PMid:15236673>

Uhlhorn M., Hurst M. \& Demmers S. 2006. Disseminated eosinophilic pulmonary granulomas in a pony. Equine Vet. Educ. 18(4):178-181. <http://dx.doi. org/10.1111/j.2042-3292.2006.tb00441.x>

USDA 2017. Equine mortality in the United States, 2015. Veterinary Services: Center for Epidemiology and Animal Health, Animal and Plant Health Inspection Service (APHIS), United States Department of Agriculture. Available at <https://www.aphis.usda.gov/animal_health/nahms/equine/ downloads/equine15/Equine15_is_Mortality.pdf> Accessed on Mar. 19, 2018.

Vaz B.B.U., Maia F.C.L., Rocha N.S. \& Thomassian A. 2009. Nasal pythiosis in horse. Med. Vet. UFRPE 3(4):27-32.

Weiblen C., Machado G., Jesus F.P.K., Santurio J.M., Zanette R.A., Pereira D.I.B., Diehl G.N., Santos L.C., Corbellini L.G. \& Botton S.A. 2016. Seroprevalence of Pythium insidiosum infection in equine in Rio Grande do Sul, Brazil. Ciência Rural 46(1):126-131. <http://dx.doi.org/10.1590/0103-8478cr20150056>

Williams K.J., Maes R., Del Piero F., Lim A., Wise A., Bolin D.C., Caswell J., Jackson C., Robinson N.E., Derksen F., Scott M.A., Uhal B.D., Li X., Youssef S.A. \& Bolin S.R. 2007. Equine multinodular pulmonary fibrosis: a newly recognized herpesvirus-associated fibrotic lung disease. Vet. Pathol. 44(6):849-862. <http://dx.doi.org/10.1354/vp.44-6-849> <PMid:18039898>

Wood J.L., Newton J.R., Chanter N. \& Mumford J.A. 2005. Association between respiratory disease and bacterial and viral infections in British racehorses. J. Clin. Microbiol. 43(1):120-126. <http://dx.doi.org/10.1128/JCM.43.1.120126.2005> <PMid:15634959> 